\title{
Uncovering Problems Caused by Mining Exploration Activities in Sangaredi
}

\author{
Ibrahima Sory Madiana Camara*, Jiand Deyi and Li Lin \\ School of Resources and Safety Engineering, Chongqing University, China
}

*Corresponding author: Ibrahima Sory Madiana Camara, School of Resources and

Safety Engineering, Chongqing University, China.

\begin{abstract}
Exploration of bauxite mining has created numerous issues of concern in communities of operations and this has triggered engineering researchers and consultancy agencies to engage in investigations to establish causes of problems reported by communities regarding mining operations. The thrust for mineral exploration in different parts of the world has led to the destruction of many communities and their habitats. This study however focuses on uncovering problems caused by mining activities in Sangaredi and therefore employed primary data collection to enhance its objectives. The study reviewed pieces of literature from books, journal articles, magazines and other periodicals published on the subject matter. This study developed suitable data collection methods, which led to the design of questionnaires used to obtain first-hand information. A sample size of 300 was used, which facilitated the gathering of first-hand information that led to thorough analysis, discussion and conclusion. The study however used descriptive statistics and correlational methods to analyses survey data with the help of statistical package for social science (SPSS). Data analyzed disclosed issues such as air pollution, water and land pollution and increased poverty, which has adversely affected the Sangaredi community. Respondents emphasized that air pollution has caused permanent blindness and lungs problems in the lives of community people and that mining exploration exercises have change the community landscape, which has caused degradation and adversely affect agricultural activities. In consideration to the aforementioned negative effects caused by mining operations, it is but fitting for government and mining companies to dialogue and find appropriate solution towards community development deterrent. This study is however significant to mining practitioners, researchers in mining and exploration activities, Sangaredi community and the Government of the Republic of Guinea.
\end{abstract}

Keywords: Uncovering problems; Mining exploration; Sangaredi community

\section{Introduction}

Exploration has brought tremendous consideration in the mining industry and has attracted considerable attention by government officials in many areas of the universe. In the African continent where minerals flooded many countries, examination of lands for suspected minerals pose several challenges, as it requires commitment on governments to engage expatriates from other parts of the world to assess and ascertain the availability of minerals in identified areas. Unlike other African countries, Guinea's commitment on exploration encompasses quantum of challenges since experts/mining companies specialists hired to conduct surveys on different parcels of land only reveal few of the minerals discovered in the said parcels of land. This makes it difficult for government officials to ascertain the different kinds of minerals discovered in sites assessed. As a result, undisclosed minerals will secretly be explored by foreign mining companies, which consequently affect the development process of the country since such secret deal will not contribute towards the country's economy. In consideration to aforementioned facts, sustainable development in all sectors of the country will be a great challenge since the dictates of the country's mining code is not adhered to Several efforts have been made by government officials to ensure that mining codes are strictly followed so that the mining sector's contribution 
towards the economy will be enormous. Organizations operating in Sangaredi have embarked on exploration activities, which have caused numerous problems for such community. However, it is from this backdrop that this study is conducted to uncover issues of concern expressed by the community. Large power has remained invested in designing a systematic background that can be recycled to reason about strategies that support maintainable progress [1-3]. This task involved some practical experiments, extending after demanding to describe what is predestined by sustainable expansion, and to establish pointers to monitor it, improves current happenings to match up with the desires of the existing issues without cooperating with upcoming generations to address their desires [4,5]. The Republic of Guinea has a rich and varied mining potential spread over its entire territory. The diversity of this potential offers investment opportunities that support very strong economic growth. However, as mineral resources are little known and valued for the moment, their contribution to supporting the country's desired economic take-off and its sustainable human development remains relatively modest [6-8]. Several internal and external factors contribute to this situation, including the fact that until 2015, the Ministry of Mines and Geology (MMG) still did not have a real (sectoral strategic development plan). To remedy this situation, the ministry has undertaken to equip itself with a set of strategic and operational planning tools, allowing it to better organize and manage its activities according to its mission and its national obligations not only to extractive industry, but also to society as a whole. The Republic of Guinea is a country rich in mineral resources; its exploitation has always followed the political evolution of the country and has been considered as a priority sector of all regimes [9]. However, despite the continuity of this operation and the place occupied by the sector expectations are far from being fulfilled [10-12]. On average, mining revenues have represented $21.9 \%$ of overall government revenues over the past 10 years compared to $40 \%$ during the 1980 s and early 1990 s $[6,13]$. Mining development has not reached its full potential, which has significantly limited its impacts on socioeconomic development and poverty reduction. Despite its wealth, most of Guinea's nine million people live in extreme poverty [14]. According to the UN Human Development Report, less than a third of adults are literate, ranking Guinea 160 out of 177 countries. Thus, unless appropriate policies and institutions are developed, mining development will not be able to constitute a source of economic development, and instability will remain a dominant factor and investments will decline even before the country has been able to achieve its desired outcome $[3,15,16]$. Already, in current mining areas, there is probability for these impacts to be felt cumulatively, with lasting effects on the well-being and health of communities, on biodiversity, as well as on human and natural resources [17]. The main challenge for mining development in Guinea is therefore: to make the exploitation of nonrenewable resources an engine of sustainable development and the fight against poverty; better manage negative environmental and social impacts that are already worrying, cumulative and long- term $[18,19]$. These are all constraints and opportunities that require at the national level an upstream strategic vision to place mining development in a sustainable ecological, monetary and social framework to strengthen the governance capacities of the State accordingly [20]. Faced with these challenges, the Republic of Guinea has initiated a major reform of the governance on mining organizations. This decline in revenues is the result of several factors, including lower taxation in sectors of mining exploration after the adoption of the 1995 mining code and the consequences of corruption in the sector's operatives [21]. The foregoing has descriptive expressed the study overview, however, subsequent elements will discuss review of literature, suitable methods used and critically analyses result obtained from survey.

\section{Literature Review}

\section{Environmental impact caused by mining exploration (Air pollution caused by mining)}

Air pollution is the introduction of any substance, which, due to its concentration, could become harmful to health and the environment. Also known as air pollution, it refers to the contamination of the air by gases, liquids and suspended solid particles, biological matter and even energy. The consequences of environmental pollution in Boké are caused by mining [22]. Bauxite dust on crops, water and their health, the populations living along the roads and mining sites of Boké periodically revolt against the authorities whom they accuse of being kind to the mining companies [23]. Mining in Guinea has many negative impacts on the villagers of mining sites, impacts on the environment and the living environment of the populations living around mining activities, and Boké is the most exposed area [24]. In fact, a dozen mining companies now reside in Boké, a situation that affects the living environment and agro-pastoral activities of the populations of this locality. Rivers are drying up; animals are no longer in places or freely graze on grasses, the excessive cutting of wood risks leading to drought [25].

\section{Land degradation caused by mining}

The main cause of land degradation is erosion. Erosion is the detachment of fragments or particles of soil or rocks from their original location by water or other geological agents such as wind, waves and ice. Erosion can either be of geological origin (geological erosion) or of human origin (accelerated erosion or soil erosion). Geological erosion is a natural phenomenon that has shaped the earth's surface over the ages or geological eras [26]. Accelerated erosion or erosion of soils due to various kinds of human activities: agricultural practices, forestry operations, pastures, construction of roads and buildings, mining operations, etc. tend to modify the phenomena of erosion, often accelerating dramatically the pace [27]. In most inhabited regions of the world, erosion and sedimentation phenomena are strongly influenced by humans. In many places, man-made erosion is predominant while natural geological erosion is only of minor importance [28]. However, 
erosion, whether natural geological or man-made, is caused by water (water erosion) or wind (wind erosion) in a rural or urban and industrial environment. Direct pressures on natural resources and ecosystems from human activities such as overgrazing, overuse of land and deforestation will lead to reduced vegetation cover, exposing soils vulnerable to erosion $[29,30]$.

\section{Water pollution caused by mining}

Water is essential for life on our planet. A prerequisite for sustainable development must ensure that watercourses are not contaminated. This is the reason for the existence of the freshwater condition in Canada. Water pollution from mining can take decades or even centuries to clear up after the mine closes [29]. These impacts depend on a variety of factors such as the sensitivity of the terrain, the composition of the minerals extracted, the type of technology employed, the skills, environmental knowledge and commitment of the community and the ability to manage and control environmental regulations [31]. One of the problems with mining is that growing technology allows mines to extract more minerals than ever before. So, mining waste has multiplied. With the advancement of technology, even more waste is expected to be produced in the future [32].

\section{Poverty caused by mining exploration}

In Guinea, one of the poorest countries in the world, bauxite mining is booming. Since 2015, the government of President Alpha Condé has made Guinea one of the world's leading exporters, and the largest exporter of this mineral to China, the world's largest aluminum producer. Guinea bauxite now accounts for a large portion of the aluminum produced internationally for automotive and aircraft parts as well as consumer products such as cans and aluminum foil $[33,34]$. Several other companies are preparing to export. Guinea, which has the largest deposits in the world, could soon become the world's largest producer of bauxite. The region of Boké, in north-western Guinea, is the focal point of recent growth in the mining sector [8].

\section{Mining effects on agriculture (Loss of land and livelihoods)}

Dozens of farmers from different villages near mining companies' extraction sites, roads and ports described how their ancestral farmland is utilized without adequate compensation. Even the little money given does not replace the benefits that families and communities derive from the land. In Guinea, rural land is organized in accordance with customary (or traditional) law. This recognizes the rights of a family, lineage or community to land based on its historical connection to it [14]. Although the Guinean land code can be interpreted as recognizing customary rights, in practice communities or individuals who occupy land under customary law must register their property or ensure that it is recorded in land plans to ensure that it is registered and be able to benefit from legal protection [35].

\section{Sustainable development (Human and Environmental sustainability)}

Human sustainability aims to maintain and improve the human capital in society. Investment in health and education systems, access to services, nutrition, knowledge and skills are all solutions under the sustainable protection of humanity. Natural resources and available space are limited, and there is a need to strike a balance between sustained growth and improved health and economic well-being for all. In a business environment, organizations see themselves as members of society and promote respect for the business value of human capital. The sustainable development of mankind focuses on the importance of anyone directly or indirectly involved in product manufacturing, service provision or wider stakeholders (the human capital of the organization). Environmental sustainability aims to improve human well-being by protecting natural capital (such as land, air, water, minerals, etc.). When initiatives and programs ensure that the needs of the people are met without jeopardizing the risks of future generations, they are defined as environmentally sustainable. Environmental sustainability emphasizes how companies can achieve positive economic results without causing short-term or long-term damage to the environment. An environmentally sustainable company seeks to integrate all four sustainable development pillars. In order to achieve this goal, everyone must be treated equally. The principles of the four pillars of sustainability stipulate that the complete sustainability issues related to all four pillars of sustainability must be solved and then maintained.

\section{Methods}

This investigation was conducted on a perspective, which constitutes uncovering problems caused by mining exploration activities in Sangaredi. The conduct of this study emanated from critical reasoning and objective analysis on issues that surrounds sustainable development. This research carefully examined issues of mining exploration from a wider perspective, through residents of Sangaredi community in the Republic of Guinea [36, 37]. This study reviewed secondary data published on the subject matter. Materials consulted are journal articles, books, magazines etc. In addition, primary data collection was also employed with the aid of questionnaires, which facilitated the gathering of first-hand information from respondents in the community. However, this study distributed 300 questionnaires to respondents through random selection to ensure a constructive balance in the research process. The sample frame used here is the community where the research is conducted $[38,39]$. There is a disparity in the random selection of sample units since the number of male respondents outweighs the female. Primary data obtained from survey was analysed with the aid of SPSS, which enabled constructive discussion and objective conclusion of the fact-finding process. Because of the nature of this study, findings were limited to the Sangaredi community and all sample units were obtained from the said community. 


\section{Result and Discussion}

This segment discussed respondent's opinion about mining activities regarding air pollution and health threats. Responses of participants unveil that many resident's health are affected by constant air pollution caused by exploration exercises. Respondents noted that toxic deposits in rivers and streams have polluted the water used by the community. In this regard, pure drinking water has become a great challenge (Table 1). Further information disclosed that extensive blasting in the community have caused several illnesses amongst inhabitants, therefore, addressing such illnesses is also a challenge because of poor health facility. Respondents indicated that the increase drop out of school going children is influenced by the mining activities since money can be earned quickly in mining sites than educational institutions. The thrust for environmental protection has been the desire of every nation in order to prevent global warming. However, respondents noted that extensive exploration exercises have led to deforestation and increased heat in the community. The effects of mining activities are depicted from the outcome of their exercises which respondents emphasized that most mining sites are flooded with water after exploration [40-42]. This situation prevents future infrastructural and other development activities. Respondents stated that accessing good health facility is a great challenge and such situation has caused the increase of infant mortality rate. Further highlights from respondents shows that previously, social relationships within the community were effective, however, the presence of mining companies and their activities have changed the social relationship amongst inhabitants (Table 2).

Table 1: Descriptive Statistics on the distribution of respondents on air pollution.

\begin{tabular}{|c|c|c|c|c|c|c|c|c|c|c|c|c|}
\hline & $\begin{array}{l}\text { N Sta- } \\
\text { tistic }\end{array}$ & $\begin{array}{c}\text { Range } \\
\text { Statis- } \\
\text { tic }\end{array}$ & $\begin{array}{l}\text { Mini- } \\
\text { mum } \\
\text { Statistic }\end{array}$ & $\begin{array}{c}\text { Maximum } \\
\text { Statistic }\end{array}$ & $\begin{array}{c}\text { Mean } \\
\text { Statis- } \\
\text { tic }\end{array}$ & $\begin{array}{l}\text { Std. } \\
\text { Error }\end{array}$ & $\begin{array}{c}\text { Std. } \\
\text { Deviation } \\
\text { Statistic }\end{array}$ & $\begin{array}{l}\text { Variance } \\
\text { Statistic }\end{array}$ & $\begin{array}{c}\text { Skew- } \\
\text { ness } \\
\text { Statistic }\end{array}$ & $\begin{array}{l}\text { Std. } \\
\text { Error }\end{array}$ & $\begin{array}{l}\text { Kurtosis } \\
\text { Statistic }\end{array}$ & $\begin{array}{l}\text { Std. } \\
\text { Error }\end{array}$ \\
\hline MRHACP & 300 & 2 & 1 & 3 & 2.42 & 0.035 & 0.778 & 0.605 & -0.887 & 0.109 & -0.782 & 0.218 \\
\hline TDRPWI & 300 & 2 & 1 & 3 & 2.3 & 0.035 & 0.782 & 0.611 & -0.581 & 0.109 & -1.135 & 0.218 \\
\hline BESIIL & 300 & 2 & 1 & 3 & 2.3 & 0.034 & 0.756 & 0.571 & -0.559 & 0.109 & -1.053 & 0.218 \\
\hline MAICSM & 300 & 2 & 1 & 3 & 2.24 & 0.034 & 0.764 & 0.584 & -0.436 & 0.109 & -1.169 & 0.218 \\
\hline EAD & 300 & 2 & 1 & 3 & 2.32 & 0.032 & 0.706 & 0.499 & -0.544 & 0.109 & -0.866 & 0.218 \\
\hline MPFEA & 300 & 2 & 1 & 3 & 2.4 & 0.03 & 0.664 & 0.441 & -0.66 & 0.109 & -0.622 & 0.218 \\
\hline HFSCC & 300 & 2 & 1 & 3 & 2.26 & 0.033 & 0.744 & 0.554 & -0.46 & 0.109 & -1.074 & 0.218 \\
\hline MCCSRI & 300 & 2 & 1 & 3 & 2.36 & 0.031 & 0.687 & 0.471 & -0.605 & 0.109 & -0.746 & 0.218 \\
\hline $\begin{array}{l}\text { Valid N } \\
\text { (listwise) }\end{array}$ & 300 & & & & & & & & & & & \\
\hline
\end{tabular}

Table 2: Descriptive Statistics on the distribution of respondents on increased poverty.

\begin{tabular}{|c|c|c|c|c|c|c|c|c|c|c|c|c|}
\hline & $\begin{array}{l}\text { N Sta- } \\
\text { tistic }\end{array}$ & $\begin{array}{c}\text { Range } \\
\text { Statis- } \\
\text { tic }\end{array}$ & $\begin{array}{c}\text { Mini- } \\
\text { mum } \\
\text { Statistic }\end{array}$ & $\begin{array}{c}\text { Maxi- } \\
\text { mum } \\
\text { Statistic }\end{array}$ & $\begin{array}{c}\text { Mean } \\
\text { Statis- } \\
\text { tic }\end{array}$ & $\begin{array}{l}\text { Std. } \\
\text { Error }\end{array}$ & $\begin{array}{c}\text { Std. } \\
\text { Deviation } \\
\text { Statistic }\end{array}$ & $\begin{array}{l}\text { Variance } \\
\text { Statistic }\end{array}$ & $\begin{array}{l}\text { Skewness } \\
\text { Statistic }\end{array}$ & Std. Error & $\begin{array}{l}\text { Kurtosis } \\
\text { Statistic }\end{array}$ & $\begin{array}{l}\text { Std. } \\
\text { Error }\end{array}$ \\
\hline AMIPC & 300 & 2 & 1 & 3 & 2.36 & 0.032 & 0.715 & 0.511 & -0.654 & 0.109 & -0.812 & 0.218 \\
\hline IECHM & 300 & 2 & 1 & 3 & 2.37 & 0.034 & 0.758 & 0.574 & -0.732 & 0.109 & -0.898 & 0.218 \\
\hline EEGAIW & 300 & 2 & 1 & 3 & 2.3 & 0.035 & 0.782 & 0.611 & -0.581 & 0.109 & -1.135 & 0.218 \\
\hline MAPEC & 300 & 2 & 1 & 3 & 2.26 & 0.033 & 0.744 & 0.554 & -0.46 & 0.109 & -1.074 & 0.218 \\
\hline $\begin{array}{l}\text { GDGC- } \\
\text { MC }\end{array}$ & 300 & 2 & 1 & 3 & 2.4 & 0.034 & 0.762 & 0.581 & -0.817 & 0.109 & -0.815 & 0.218 \\
\hline CMAPS & 300 & 2 & 1 & 3 & 2.4 & 0.035 & 0.788 & 0.621 & -0.838 & 0.109 & -0.884 & 0.218 \\
\hline SICUEA & 300 & 2 & 1 & 3 & 2.36 & 0.031 & 0.687 & 0.471 & -0.605 & 0.109 & -0.746 & 0.218 \\
\hline TPEFC & 300 & 2 & 1 & 3 & 2.21 & 0.034 & 0.766 & 0.587 & -0.377 & 0.109 & -1.21 & 0.218 \\
\hline $\begin{array}{l}\text { Valid N } \\
\text { (list- } \\
\text { wise) }\end{array}$ & 300 & & & & & & & & & & & \\
\hline
\end{tabular}

This study has disclosed quantum information regarding community issues and this table describes how mining activities has increased poverty in the community instead of alleviating it. It is registered by many respondents that intensive mining activities have increased poverty in the community. Activities of mining and exploration have not only increased poverty, but also increased hunger, starvation and malnutrition. The wellbeing of people in every community is a paramount concern since psychological and emotional issues are generated through unpleasant living condition. However, respondents mentioned that extensive exploration has greatly affected inhabitants' wellbeing. Education is the thrust for every nation's development and negligence on its path adversely 
affect all sectors of operations. Respondents registered that intensive mining activities have disturbed educational operations in the community. They added that this has also affected human capital growth in surrounding communities. Maintaining gender parity in a community flooded with mining activities encompasses enormous challenges. In this regard, respondents disclosed that gender disparity in on the increase and respect for female counterpart is not evident in such community. Streams in which inhabitants fetch water has been polluted by toxic deposits by mining companies, in their quest to unearth precious minerals from the ground. This situation has extensively affected several sectors of agricultural activities in the community. Environmental hazards have increased because of poor sanitary operations caused by extensive mining and exploration activities [43-45]. Respondents indicated that because of extensive exploration activities, the community is deprived of effective electricity supply. They added that power supply is classified according to economic status. This has led to the deprivation of lower-class consumers (Table 3).

Table 3: Descriptive Statistics on the distribution of respondents on water and land pollution.

\begin{tabular}{|c|c|c|c|c|c|c|c|c|c|c|c|c|}
\hline & $\begin{array}{c}\text { N } \\
\text { Sta- } \\
\text { tistic }\end{array}$ & $\begin{array}{l}\text { Range } \\
\text { Statis- } \\
\text { tic }\end{array}$ & $\begin{array}{l}\text { Mini- } \\
\text { mum } \\
\text { Statistic }\end{array}$ & $\begin{array}{l}\text { Maxi- } \\
\text { mum } \\
\text { Statistic }\end{array}$ & $\begin{array}{c}\text { Mean } \\
\text { Statistic }\end{array}$ & $\begin{array}{l}\text { Std. } \\
\text { Error }\end{array}$ & $\begin{array}{c}\text { Std. } \\
\text { Deviation } \\
\text { Statistic }\end{array}$ & $\begin{array}{l}\text { Variance } \\
\text { Statistic }\end{array}$ & $\begin{array}{c}\text { Skew- } \\
\text { ness } \\
\text { Statistic }\end{array}$ & $\begin{array}{l}\text { Std. } \\
\text { Error }\end{array}$ & $\begin{array}{l}\text { Kurtosis } \\
\text { Statistic }\end{array}$ & $\begin{array}{l}\text { Std. } \\
\text { Error }\end{array}$ \\
\hline TDRAFEC & 300 & 2 & 1 & 3 & 2.19 & 0.034 & 0.755 & 0.57 & -0.337 & 0.109 & -1.179 & 0.218 \\
\hline SSNVTME & 300 & 2 & 1 & 3 & 2.37 & 0.031 & 0.703 & 0.494 & -0.66 & 0.109 & -0.76 & 0.218 \\
\hline GAGIEA & 300 & 2 & 1 & 3 & 2.27 & 0.033 & 0.734 & 0.538 & -0.471 & 0.109 & -1.025 & 0.218 \\
\hline LCGOC & 300 & 2 & 1 & 3 & 2.22 & 0.035 & 0.783 & 0.613 & -0.407 & 0.109 & -1.26 & 0.218 \\
\hline CEACPL & 300 & 2 & 1 & 3 & 2.16 & 0.035 & 0.785 & 0.616 & -0.29 & 0.109 & -1.322 & 0.218 \\
\hline SDCEIE & 300 & 2 & 1 & 3 & 2.41 & 0.03 & 0.68 & 0.463 & -0.725 & 0.109 & -0.612 & 0.218 \\
\hline JCCDJ & 300 & 2 & 1 & 3 & 2.35 & 0.033 & 0.727 & 0.529 & -0.646 & 0.109 & -0.867 & 0.218 \\
\hline $\begin{array}{c}\text { Valid N } \\
\text { (listwise) }\end{array}$ & 300 & & & & & & & & & & & \\
\hline
\end{tabular}

Description of water and land pollution is relevant in environmental protection. Many mining exercises in the world have left communities with unpleasant living condition, which has caused devastating effects on those communities. Respondents therefore registered that, toxic deposits in rivers have caused unpleasant fishing activities, which has deprived fishermen from big catch. Soil nutrients contribute towards effective cultivation and plants growth. In this regard, surface of the soil should not be contaminated with any dangerous substance. However, respondents noted that surface soil nutrients have lost its value because of toxic mining elements. Gracing, which enhances animal wellbeing is also affected, as cattle cannot grace in areas with intensive exploration exercises. Extending mining operations in different parts of the community creates infringement into private lands, which are utilized by mining companies with unsatisfactory compensation to their owners. However, larger share of such compensation goes to government officials. Peaceful coexistence is the desire of every community since everyone can go about his/her normal duties without interruption. Nevertheless, respondents mentioned that continuous exploration have caused unrest and affect community peaceful living. Respondents indicated that sustainability in different community engagements is interrupted by exploration activities $[9,46,47]$. The legal expression says that everyone is equal before the law, but it is difficult to see such expression manifest in every court proceedings. Survey results disclosed that the justice system in the community is affected since status is greatly concern in the dispensation of justice (Table 4).

Table 4: Correlations on Environmental Impacts of Mining.

\begin{tabular}{|c|c|c|c|c|c|c|c|c|c|c|}
\hline & 1 & 2 & 3 & 4 & 5 & 6 & 7 & 8 & 9 & 10 \\
\hline MECNH & 1 & & & & & & & & & \\
\hline DTEMAS & 0.915 & 1 & & & & & & & & \\
\hline EBMCN & 0.927 & 0.893 & 1 & & & & & & & \\
\hline TDRPWI & 1 & 0.915 & 0.927 & 1 & & & & & & \\
\hline MAICSM & 0.953 & 0.967 & 0.877 & 0.953 & 1 & & & & & \\
\hline EAD & 0.915 & 0.963 & 0.923 & 0.915 & 0.935 & 1 & & & & \\
\hline ECRIDTP & 0.915 & 0.963 & 0.923 & 0.915 & 0.935 & 1 & 1 & & & \\
\hline EAGAEE & 0.932 & 0.981 & 0.911 & 0.932 & 0.95 & 0.981 & 0.981 & 1 & & \\
\hline MOIEIAC & 0.938 & 0.949 & 0.861 & 0.938 & 0.983 & 0.918 & 0.918 & 0.934 & 1 & \\
\hline FLLTED & 0.918 & 0.964 & 0.868 & 0.918 & 0.965 & 0.93 & 0.93 & 0.947 & 0.983 & 1 \\
\hline
\end{tabular}


This section shows correlation amongst the different construct of mining exploration. There are indications that extensive mining and exploration activities have led to changes in nature and its habitat. In addition, evidence shows that toxic deposits endlessly destroy soil nutrients, which consequently hinders the progress of farming activities. As a result, it also causes poor road network, which deprives inhabitants of quick access to neighboring villages. Evidence further disclosed that, toxic deposits in streams pollute drinking water. However, it is emphasized that mining activities have led to many children dropping out of school in search of fast money. This has restrained the development of the community's human capital. Quantum evidence disclosed that extensive exploration has led to deforestation, which has increased heat in the community and deprive cattle from gazing. It is also noted that grazing is not only deprived by deforestation but also deposit of dangerous waste from mining activities. Since mining operations focus purely on exploring minerals, educational activity is not their primary concern, therefore education in the community is influenced by constant mining and exploration activities. Negligence in environmental impact assessments causes numerous environmental problems. However, it is disclosed that mining companies in Sangagredi are not committed to environmental assessment activities [48-50]. It is emphasized that bountiful harvest is no longer visible because of soil contamination by toxic elements deposited on the surface of the earth. In consideration to elements discussed, it is evident that there is positive correlation amongst the various components [51-55].

\section{Conclusion}

Conducting investigation regarding mining exploration involves an assessment of issues from a wider spectrum to ascertain the relevance of the subject been studied. The study employed primary and secondary data collection methods to establish constructive assessment of components being studied. In this regard, the study reviewed pieces of literature form sources published on the subject matter. The review process involves published articles, books, magazines and other periodicals. Reviewed contents were adopted, which helps to identify limitations and gaps of previous studies. The study further developed questionnaires using the Linkert scale with the following description $1=$ Strongly Disagree, $2=$ Disagree, $3=$ Neutral, 4=Agree, 5=Strongly Agree. The community in which the investigation is conducted served as the sample frame and inhabitants are described as sample units with the following designations: businessperson, farmer, technician and unskilled. 300 people were selected randomly from different works of life who served as respondents in the study. Among the 300 people selected as representative sample size, 200 are men whilst 100 are women. Questionnaires distributed provided series of information that led to constructive analysis, discussion and objective conclusion. The study further employed descriptive statistics and correlational methods in its analysis conducted using statistical package for social sciences (SPSS). Results obtained from the survey data analysed disclosed air pollution, water and land pollution and increased poverty as issues affecting the community. Respondents emphasized that, the aforementioned elements are key destructive components that has ravaged the community. They however affirmed that if government could constantly monitor and engage mining companies on their operations, such problems will be minimized. The added that because of mining exploration activities, the community's landscape and its habitat have greatly been affected. Even though this study is limited to Sangaredi community, future research could consider extending to other communities and increase the sample size or possibly employ different research method.

\section{Acknowledgement}

None.

\section{Conflict of Interest}

No conflict of interest.

\section{References}

1. Heckenmüller M, D Narita, G Klepper (2014) Global availability of phosphorus and its implications for global food supply: an economic overview. Kiel Working Paper No. 1897. Kiel Institute for Working Economy, Kiel, Germany.

2. Hore-Lacy I,ed (2016) Uranium for nuclear power. Ressources, mining and transformation to fuel. Elsevier, Woodhead Publishing, Amsterdam.

3. Hudson-Edwards, KA, HE Jamieson, and BG Lottermoser (2011) Mine wastes: past, present, future Elements 7: 375-380.

4. Jackson RB, A Vengosh, JW Carey, RJ Davies, TH Darrah, FO'Sullivan, et al (2014) The environmental costs and benefits of fracking. Annu. Rev. Environ. Resour 39: 327-362.

5. Jaskoski M (2014) Environmental licensing and conflict in Peru's mining sector: a path-dependent analysis. World Dev 64: 873-883.

6. Wells PG (2017) The iconic torrey canyon oil spill of 1967 - Marking its legacy Mar Pollut Bull 115: 1-2.

7. World Bank (2002) Treasure or Trouble? Mining in developing countries. World Bank and International Finance Corporation.

8. Zalasiewic J, M Williams, CN Waters, AD Barnosky, J Palmesino, et al. Scale and diversity of the physical technosphere: A geological perspective. The Anthropocene Review 4: 9-22.

9. Nordstrom, DK (2011) Mine waters: acidic to Circumneutral. Elements $7: 393-398$

10. Bauer F, Matzler K (2014) Antecedents of M\& A success: The role of strategic complementarity, cultural fit, and degree and speed of integration. Strategic Management Journal 35(2): 269-291.

11. Carvalho FP, JM Oliveira, and M Malta (2014) Exposure to radionuclides in smoke from vegetation fires. Sci. Total Environ 472: 421-424.

12. Barai P, Mohanty P (2014) Role of industry relatedness in performance of Indian acquirers-Long and short run effects. Asia Pacific Journal of Management 31(4): 1045-1073.

13. Basuil DA, Datta DK (2015) Effects of industry-and region-specific acquisition experience on value creation in cross-border acquisitions: The moderating role of cultural similarity. Journal of Management Studies 52(6): 766-795.

14. Mudroch A, U Stottmeister, C Kennedy, H Klapper, eds (2002) Remediation of abandoned surface coal mining sites. Series: Environmental Engineering. Springer, New York, pp. 175. 
15. Hilson G (2002) An overview of land use conflicts in mining communities. Land Use Policy 19: 65-73.

16. Carvalho FP, F Conceição, F Catuane, S Taímo, JM Oliveira et.al (2017) Heavy mineral sands exploitation and exposure to ionizing radiation in Mozambique. IAEA Proceedings of NORM VIII Conference heldin Rio de Janeiro 2016, International Atomic Energy Agency, Vienna.

17. Rosemarin A (2010) Peak phosphorus, the next inconvenient truth? 2nd International Lecture Series on sustainable sanitation. World Bank Manila.

18. Chittoor R, Kale P, Puranam P (2015) Business groups in developing capital markets: Towards a complementarity perspective. Strategic Management Journal 36(9): 1277-1296.

19. Lima IB, WL Filho (2015) Rare Earths Industry: technological, Economic and Environmental Implications. Elsevier, Amsterdam.

20. Bebbington A, M Williams 2008 Water and mining conflicts in Peru. Mt Res Dev 28:190-195

21. Bury JT (2004) Livelihoods in transition: transnational gold mining operations and local change in Cajamarca, Peru. Geogr J 170: 78-91.

22. Carvalho FP, JM Oliveira, M Malta (2016) Preliminary assessment of uranium mining legacy and environmental radioactivity levels in Sabugal region, Portugal. Int J Energy Environ Eng 7: 399-408.

23. Cordell D, JO Drangert, S White (2009) The story of phosphorus: global food security and food for thought. Glob Environ Change 19: 292-305.

24. Carvalho FP, R Edge (2013) Uranium mining and milling: the need for reference materials in environmental radioactivity monitoring programmes. Int J Environ Stud 70: 603-610.

25. Hossain D, Gorman D, Chapelle B, Mann W, Rod Saal, et al. (2013) Impact of the mining industry on the mental health of landholders and rural communities in southwest Queensland. Aust Psychiatry 21: 32-7.

26. Chari MD, Dixit J (2015). Business groups and entrepreneurship in developing countries after reforms. Journal of Business Research 68(6): 1359-1366.

27. Chang SE, J Stone, K Demes, M Piscitelli (2014) Consequences of oi spills: a review and framework for informing planning. Ecol Soc 19: 26.

28. Fernandez-Lozano J, G Gutierrez-Alonsoa, MA Fernandez-Moran (2015) Using airborne LiDAR sensing technology and aerial orthoimages to unravel roman water supply systems and gold works in NW Spain (Eria valley, León). J Archaeol Sci 53: 356-373.

29. Carvalho FP (2011) Environmental radioactive impact associated to uranium production. Am. J. Environ Sci 7: 547-553.

30. Gilbert N (2009) The disappearing nutrient. Nature 461: 716-718.

31. Anttonen M, Kumpula J, Colpaert A (2011) Range selection by semidomesticated reindeer (Rangifer tarandus tarandus) in relation to infrastructure and human activity in the boreal forest environment, northern Finland. Arctic, pp. 1-14.

32. Freese B (2004) Coal: a human history. Penguin Books, London 137 pp.

33. Colli A, Colpan AM (2016) Business groups and corporate governance: Review, synthesis, and extension. Corporate Governance: An International Review,24(3): 274-302.

34. Edler, J, Georghiou L, Blind K, Uyarra E (2012) Evaluating the Demand Side: New Challenges for Evaluation. Research Evaluation 21(1): 33-47.

35. Gupta A, Upadhyay D (2012) Impact of effectiveness of performance management system on employee satisfaction and committment. International Journal of Management, IT and Engineering 2(7).
36. Giangreco A, Carugati A, Sebastiano A, Tamimi HA (2012) War outside, ceasefire inside: An analysis of the performance appraisal system of a public hospital in a zone of conflict. Eval Program Plann 35(1): 161-170.

37. Gibson G, Klinck J (2005) Canada's resilient north: the impact of mining on aboriginal communities. Pimatisiwin 3: 116-39.

38. Dineen BR, Williamson IO (2012) Screening-oriented recruitment messages: Antecedents and relationships with applicant pool quality. Human Resource Management 51: 343-360.

39. Gomes Mejia LR, Balkin, DB Cardy RL (2012) Managing Human Resources. Prentice Hall.

40. Gordon RB, M Bertram, TE Graedel (2006) Metal stocks and sustainability. Proc Natl Acad Sci 103: 1209-1214.

41. Fleming DA, Measham TG (2014) Local job multipliers of mining. Resour Policy 41: 9-15.

42. Kashmiri S, Mahajan V (2014) Beating the recession blues: Exploring the link between family ownership, strategic behaviour, and firm performance during recessions. International Journal of Research in Marketing 31(1): 78-93.

43. Flor P (2014) Mining and economic development in Peru. ReVista, Harvard Review of Latin America, Harvard University, Rockfeller Centre.

44. Le SA, Park JC, Kroll M (2014) Differential effects of pre-and postacquisition R \& D expenditures on post-acquisition performance. Journal of Business Research 67(2): 92-99.

45. Jain R, ZC Cui, JK Domen (2016) Environmental impact of mining and mineral processing. Elsevier, Butterworth-Heinemann Publ, pp. 322.

46. Johnson CJ, Boyce MS, Case RL, Cluff HD, Gau RJ, Gunn A, Mulders R. (2005) Cumulative effects of human developments on arctic wildlife. Wildl Monogr 160: 1-36.

47. Kang, C, Germann F, Grewal R (2016) Washing away your sins? Corporate social Responsibility, corporate social irresponsibility, and firm performance. Journal of Marketing 80(2): 59-79.

48. Gubbi SR, Aulakh PS, Ray S (2015) International search behavior of business group affiliated firms: Scope of institutional changes and intragroup heterogeneity. Organization Science 26(5): 1485-1501.

49. Gaur AS, Kumar V, Singh D (2014) Institutions, resources, and internationalization of emerging economy firms. Journal of World Business 49(1): 12-20

50. Bury JT (2002) Livelihoods, mining and peasant protests in the Peruvian Andes. J Lat Am Geogr 1: 1-19.

51. Alon I, Fetscherin M, Gugler P (2012) Chinese international investments. Basingstoke UK: Palgrave Macmillan s.

52. Basov V (2015) True giants of mining: World's top 10 iron ore mines.

53. Brown LR (2011) World on the edge: how to prevent environmental and economic collapse. W.W. Norton \& Company, New York, London, pp. 240

54. Carvalho FP (2017) Pesticides, environment and food safety. Food Energy Secur 6: 48-60.

55. Carvalho FP, MJ Madruga, MC Reis, JG Alves, JM Oliveira, et al. (2007) Radioactivity in the environment around past radium and uranium mining sites of Portugal. J Environ Radioact 96: 39-46. 